\title{
PDGFRB wt Allele
}

National Cancer Institute

\section{Source}

National Cancer Institute. PDGFRB wt Allele. NCI Thesaurus. Code C52203.

Human PDGFRB wild-type allele is located within 5q31-q32 and is approximately $42 \mathrm{~kb}$ in length. This allele, which encodes beta platelet-derived growth factor receptor protein, is involved in mitogenesis for cells of mesenchymal origin. A translocation between chromosomes 5 and 12, that fuses this gene to that of the translocation, ETV6, leukemia gene, results in chronic myeloproliferative disorder with eosinophilia. 